https://doi.org/10.19195/2082-8322.12.6

Mariusz Bartodziej

ORCID: 0000-0002-2112-8914

Uniwersytet Wrocławski

\title{
Gra zmysłów. Multimodalność w polskim reportażu na przykładzie "Outriders"
}

„Funkcjonujemy w czasach walki o uwagę odbiorców”1 - podkreśla Natalia Osica, popularyzatorka nauki. Weronika Świerczyńska-Głownia wskazuje, że „oferowanie wyłącznie interesujących treści nie gwarantuje sukcesu”, dlatego media stale poszukują narzędzi pozwalających im utrzymać skuteczność komunikacji, a co za tym idzie - swoją pozycję na tle konkurencji ${ }^{2}$. W epoce zalewu informacji ${ }^{3}$, wszechobecnego dostępu do nich i hipertekstualności trudno oprzeć się pokusie nieustannego zmieniania przyswajanych treści bądź kanału, przez który do nas docierają. Szczególnie dotyczy to osób mających styczność z technologią i Internetem na co dzień. „Cyfrowi tubylcy przyzwyczajeni do wielozadaniowości - pisze Magdalena Trysińska - mają problem ze skupieniem uwagi na jednym zadaniu" 4 . Prędzej więc wezmą przy śniadaniu do ręki smartfona i przejrzą specjalnie przygotowany dla nich zestaw spersonalizowanych informacji bądź skorzystają z mediów społecznościowych, niż zrobią przegląd prasy lub posłuchają analogowego radia. Wydawcy chcący pozostać na rynku musieli uwzględnić tę zmianę zachowań ${ }^{5}$, ponieważ Internet dokonał

${ }^{1}$ Funkcjonujemy w czasach walki o uwagę odbiorców, z Natalią Osicą rozmawia Mariola Wilczak, „Biuletyn Polonistyczny” 1.08.2018, s. 3.

2 W. Świerczyńska-Głownia, Multiplatformowa promocja treści. Prasa, radio i telewizja na sfragmentaryzowanym rynku mediów, „Zeszyty Prasoznawcze” 62, 2019, nr 1, s. 45.

3 Zob. W. Babik, O natłoku informacji i związanym z nim przeciążeniu informacyjnym, Kraków 2012.

${ }^{4}$ M. Trysińska, Multimodalność w szkole. Edukacyjna wartość tekstów multimodalnych na przykładzie portalu Scholaris.pl, [w:] Współczesne media. Media multimodalne, t. 2. Multimodalność mediów elektronicznych, red. I. Hofman, D. Kępa-Figura, Lublin 2018, s. 179.

${ }^{5}$ M. Różycka, Wykorzystanie najnowszych narzędzi cyfrowych w pracy regionalnych dziennikarzy na przykładzie „Dziennika Zachodniego”, „Zarządzanie w Kulturze” 17, 2016, nr 2, s. 168. 


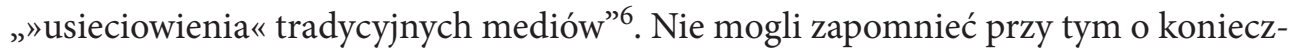
ności „adaptacji trendów funkcjonujących $\mathrm{w}$ innym obcym medium”. Jako jeden $\mathrm{z}$ wielu gatunków do sieci przeniknął reportaż (znany pierwotnie z prasy i książek) — nie tylko w formie „śmieci reportażowych”, jak określono część tekstów z blogosfery ${ }^{8}$. Paulina Buczek konstatuje: „rozwój nowych mediów niesie za sobą odrodzenie i ewolucję literatury faktu"'.

Maria Krauz zaznacza, że „współczesny odbiorca mediów” oczekuje „rzetelności i atrakcyjnej formy przekazu"10. By wspomniana ewolucja mogła zajść, powinna mieć więc związek między innymi z (modnym już ${ }^{11}$ ) pojęciem „multimodalności”. Dotyczy ona obecności „wielu kodów” i odbierania treści „na kilku poziomach”, czyli porozumiewania się za pomocą więcej niż jednego zmysłu ${ }^{12}$. W jej kontekście pojawia się niejednokrotnie w dyskursie termin „multimedialność”. Nie są one tożsame, a ich współwystępowanie jest nieobligatoryjne. Różnicę trafnie ujmuje Magdalena Trysińska: „multimedialność” jest ściśle powiązana z technologią i wykorzystaniem środków technicznych, a „multimodalność” „odnosi się do tekstu i jego wieloznakowej organizacji"13. Istotne jest przy tym to, że wykorzystywane systemy semiotyczne nie istnieją obok siebie, tylko wzajemnie się przenikają i na siebie oddziałują ${ }^{14}$. Jolanta Maćkiewicz obrazuje to w następujący sposób: „Komunikat multimodalny jest jak partytura orkiestrowa, gdzie poszczególne partie instrumentalne współgrają ze sobą, tworząc całość, która nie jest tylko i po prostu sumą części”'15.

Należy zaznaczyć, iż multimodalność nie jest niczym nowym. Opiera się na niej międzyludzka komunikacja „twarzą w twarz” (patrzymy na siebie i mówimy, angażując wzrok i słuch) ${ }^{16}$, od wieków jest wykorzystywana w malarstwie (poprzez inskryp-

6 B. Skowronek, Językowe odmiany medialne wobec przemian wspótczesnej technokultury, „Медиалингвистика" 5, 2018, nr 3, s. 335.

${ }^{7}$ H. Stöckl, Mediolingwistyka. O statusie i metodach (nadal) konstytuującej się dziedziny badawczej, „Tekst i Dyskurs - Text und Diskurs” 8, 2015, s. 47.

8 W. Furman, A. Kaliszewski, K. Wolny-Zmorzyński, Gatunki dziennikarskie. Teoria, praktyka, ję$z y k$, Warszawa 2006, s. 83.

9 P. Buczek, Wpływ nowych mediów na ewolucję literatury faktu: analiza reportażu multimedialnego Jacka Hugo-Badera „Boskie światło”, „Civitas et Lex” 2015, nr 3, s. 7.

${ }^{10}$ M. Krauz, Zatrzymać uwagę widza. Językowe i pozajęzykowe środki perswazji w telewizyjnych programach informacyjnych, „Медиалингвистика” 5, 2018, nr 3, s. 380.

11 J. Maćkiewicz, Badanie mediów multimodalnych - multimodalne badanie mediów, „Studia Medioznawcze - Media Studies" 69, 2017, nr 2, s. 33.

12 M. Krauz, op. cit., s. 381.

13 M. Trysińska, op. cit., s. 181.

14 B. Skowronek, op. cit., s. 331.

15 J. Maćkiewicz, op. cit., s. 35.

16 A. Karaśkiewicz, Spójność multimodalnego przekazu reporterskiego w krótkiej relacji telewizyjnej „na żywo”, Poznań 2016, s. 106. 
cje dodawane na obrazach) ${ }^{17}$, czy wreszcie wiąże się z każdym komunikatem medialnym, nawet prasowym (przez opatrzenie tekstu fotografią) ${ }^{18}$. Jednak, jak zwraca uwagę Maćkiewicz, tym, co się zmieniło, jest „większy udział kodów ikonicznych [...] i nowe sposoby łączenia ze sobą elementów należących do różnych systemów semiotycznych" ${ }^{19}$. Rosnąca potrzeba podawania informacji w łatwej do przyswojenia formie ${ }^{20}$ i rosnący poziom kompetencji odbiorców w zakresie hipertekstowości ${ }^{21}$ doprowadziły do tego, iż komunikacja multisensoryczna stała się normą ${ }^{22}$, a multimodalność zdominowała przekaz w Internecie - z jednej strony odzwierciedlając współczesne porozumiewanie się, a z drugiej umożliwiając spotęgowanie oczekiwanej przez nadawców skuteczności komunikatów ${ }^{23}$. W ten sposób dochodzimy do ewolucji reportażu, który przeniósł się do sieci między innymi „z papieru”, przyjmując multimedialną (a zarazem multimodalną) formę poprzez połączenie tekstu, dźwięku i obrazu (statycznego - fotografii i dynamicznego - filmu). Multimedialność stała się po części, w obliczu rozwoju Internetu, przymusem ${ }^{24}$, a ponadto umożliwiła „wielowymiarowy odbiór i poznanie”25.

\section{Od "The New York Times" do "Outriders"}

Gdy Kamil Bałuk opisywał w 2014 roku projekty multimedialne przygotowywane przez „The New York Times”, skonstatował, że na polskim rynku brakuje podobnych, znaczących realizacji ${ }^{26}$. W listopadzie rok później dziennikarze „Dziennika Zachodniego", Karol Gruszka i Maria Zawała, opublikowali doceniany interaktywny reportaż Pokłady pamięci. Opowiada on o najstarszej dzielnicy Katowic, Dębie, i kopalni

17 E. Chrzanowska-Kluczewska, Wycieczka multimodalna. Rola wstawek tekstowych w wizualnych dziełach sztuki, [w:] Język i tekst w ujęciu strukturalnym i funkcjonalnym, red. A. Dudziak, J. Orzechowska, Olsztyn 2017, s. 56.

18 J. Maćkiewicz, op. cit., s. 40.

19 Ibidem.

20 G. Antos, R. Opiłowski, W drodze do lingwistyki obrazu. Kierunki rozwoju nowej subdyscypliny lingwistycznej z perspektywy polsko-niemieckiej, „Tekst i Dyskurs - Text und Diskurs” 8, 2015, s. 13.

${ }^{21}$ H. Stöckl, op. cit., s. 47.

22 M. Krauz, op. cit., s. 390.

${ }^{23}$ K. Sobstyl, Funkcje obrazu i tekstu w internetowych ogłoszeniach schroniska dla bezdomnych zwierząt w Lublinie, [w:] Współczesne media..., s. 167.

${ }^{24}$ K. Bałuk, Nowe formy gatunków dziennikarskich w sieci. Przykład projektów „The New York Times”, „Dziennikarstwo i Media” 5, 2014, s. 83.

25 A. Jakubas, Reportaż wirtualny. Nowe dziennikarstwo internetowe, [w:] Literatura bez fikcji. Między sztuką a codziennością. W stronę nowej syntezy, red. M. Hopfinger, Z. Ziątek, T. Żukowski, Warszawa 2018, s. 135.

${ }^{26}$ K. Bałuk, op. cit., s. 94. 
„Gottwald”27. Rozwój tej formy gatunkowej postępował. Od 2017 roku funkcjonuje grupa „Outriders”, której inicjatorami są Anna i Jakub Górniccy ${ }^{28}$. Fundusze na rozpoczęcie działalności pozyskali poprzez crowdfunding, czyli internetową zbiórkę (z tego powodu i dlatego, że wiele projektów jest dofinansowanych, wszystkie materiały są dostępne bezpłatnie $)^{29}$. Projekt otrzymał już między innymi nominację do MediaTorów w kategorii „Inicjator”30, a także nagrodę Grand Press Digital ${ }^{31}$. Zrzesza ludzi z całego świata - nie tylko dziennikarzy i fotoreporterów, ale nawet programistów. Ci ostatni są niezbędni do tworzenia wartościowych interaktywnych materiałów, a między innymi takie zadanie wyznaczają sobie „Outriders”:

Tradycja reportażu łączy się z nowoczesnymi narzędziami. Wykorzystujemy pasję do technologii, aby pokazywać skomplikowane historie. Praca nad takimi produkcjami wymaga czasu - tygodni, a często miesięcy — i angażuje cały zespół od reportera po programistę. Wszystko po to, by przygotować reportaż ciekawy wizualnie, treściowo i technologicznie ${ }^{32}$.

„Outriders” funkcjonują wyłącznie w wersji cyfrowej. Materiały na swojej stronie sortują pod kątem miejsca, którego dotyczą, tematu oraz formy. W ostatniej kategorii wydzielają cztery podkategorie: „Artykuły” (wszystkie teksty „prasowe”), „Brief” (zestaw cotygodniowych informacji ze świata), „Stories” (interaktywne reportaże w formacie na smartfona) i „Interaktywnie”. Dla niniejszego artykułu istotna jest ostatnia z nich. Zawiera dwadzieścia sześć publikacji ${ }^{33}$ : „Analizy i podsumowania” (cztery), „Opowieści multimedialne” (sześć), „Projekty transgraniczne” (trzy) oraz „Reportaże interaktywne” (trzynaście). W „Analizach i podsumowaniach” odnajdziemy zbiór krótkich notek $\mathrm{z}$ wydarzeń $\mathrm{z}$ całego świata $\mathrm{z}$ danego roku, dlatego trudno rozpatrywać je w kategorii reportażu. W przypadku pozostałych materiałów jest to możliwe, dlatego skoncentruję się na nich. By dostosować się do ograniczeń objętościowych wyznaczanych przez formę artykułu oraz by spróbować zachować proporcję, przyjrzę się jednemu projektowi transgranicznemu (Deep Breath), dwóm opowieściom multimedialnym (Dziewczynka z kiduszowym pucharkiem oraz Rzemieślnik z miasta pianin i fortepianów), a także trzem reportażom interaktywnym (Mogadishu, Linia, i Trans-Ukraina).

Wybrane publikacje rozpatrzę w zakresie ich multimodalności, zważając na kilka kwestii związanych $\mathrm{z}$ tym zagadnieniem. Z którymi modalnościami mamy do czy-

27 K. Gruszka, M. Zawała, Pokłady pamięci, https://plus.dziennikzachodni.pl/poklady-pamiecipodazaj-sladami-gornikow-reportaz-interaktywny/ar/c3-9061815 (dostęp: 16.11.2019).

28 Strona internetowa inicjatywy „Outriders”, https://outride.rs/pl/ (dostęp: 16.11.2019).

29 Outriders - jakościowe dziennikarstwo z całego świata, https://wspieram.to/outriders (dostęp: 16.11.2019).

30 Strona internetowa nagrody MediaTory, http://www.mediatory.pl/o-plebiscycie/nominowani-2017/ (dostęp: 16.11.2019).

31 Strona internetowa nagrody Grand Press, https://grandpress.press.pl/ (dostęp: 16.11.2019).

32 Outriders - jakościowe dziennikarstwo...

33 Strona internetowa inicjatywy „Outriders”, https://outride.rs/pl/interaktywnie/ (dostęp: 17.11.2019). 
nienia: z językiem, obrazem, muzyką, odgłosami ${ }^{34}$ ? Jakie relacje zachodzą pomiędzy poszczególnymi systemami semiotycznymi w obrębie tekstu: dominacja, rozdźwięk, redundancja czy komplementarnośc ${ }^{35}$ ? Wreszcie ocenię, czy autorzy potrafili wykorzystać w praktyce swoją wiedzę o multimodalności ${ }^{36}$, uwzględniając niełatwy (mimo płynących z niego korzyści poznawczych) odbiór komunikatów tego rodzaju. Jak wyjaśnia Jolanta Maćkiewicz:

Odkrywanie czy raczej negocjowanie sensów, które zachodzi w procesie interpretacji, odbywa się $\mathrm{w}$ ramach rozmaitych interakcji: między odbiorcą a przekazem, między przekazem a (szeroko rozumianym) kontekstem, między odbiorcą a kontekstem, między poszczególnymi składnikami przekazu. [...] Jeżeli któryś z elementów (słowny czy obrazowy) stanowi źródło kłopotów interpretacyjnych, odbiorca szuka wskazówek w sąsiednim elemencie (potwierdzają to badania okulograficzne) $)^{37}$.

\section{Multimodalność w praktyce}

Deep Breath to reportaż o zmaganiu się ze smogiem w kilku miastach (między innymi w Bombaju, Krakowie i Meksyku) położonych na różnych kontynentach ${ }^{38}$. Zaczyna się od możliwości podania swojej lokalizacji, by w trakcie lektury uzyskać informację o stanie powietrza w okolicy. Mamy w tym przypadku do czynienia w pewnym stopniu z dialogowością, „jednym z głównych wyróżników współczesnych mediów”39. Po wejściu w materiał ukazuje nam się mapa świata z zaznaczonymi miejscowościami. Korzystając z klawiatury bądź pokrętła myszki, zmieniamy slajdy i linearnie zagłębiamy się w narrację. Najpierw pojawia się na ekranie zdjęcie trójki osób w antysmogowych maskach, a dopiero po kolejnym ruchu opis rodziny Yang $\mathrm{z}$ Chin, co stanowi intrygujące przejście. Następnie tekstowy opis smogu jest uzupełniony o jego ruchomą wizualizację wraz z wypisanymi składnikami, obrazując powszechnie opisywany i omawiany problem. Podawane $\mathrm{w}$ formie wykresu dane $\mathrm{z}$ trzech okresów zmieniają się automatycznie, a w tle zobrazowane jest to, co ujmują. Zautomatyzowanie utrudnia jednak analizę informacji. Gdy czytamy o zanieczyszczeniu powietrza w Meksy$\mathrm{ku}, \mathrm{w}$ tle oglądamy wideo $\mathrm{z}$ dźwiękiem $\mathrm{z}$ kamery ustawionej przy zakorkowanej ulicy, byśmy mogli doświadczyć tego, co bohaterowie opowieści. Na reportaż składa się także wywiad $z$ jednym $z$ kabulskich lekarzy, opatrzony na poprzednim slajdzie cytatem $\mathrm{z}$ rozmowy. $\mathrm{W}$ materiale dominuje więc tekst, uzupełniony o materiały dźwiękowe

34 G. Antos, R. Opiłowski, op. cit., s. 14.

35 M. Krauz, op. cit., s. 381.

36 J. Dąbała, Multimodalność mediów w czasach audiowizualności a błędy w komunikowaniu, „Zeszyty Prasoznawcze" 60, 2017, nr 4, s. 712.

37 J. Maćkiewicz, Multimodalność a perswazja (na przykładzie tygodników opinii), „Prace Komisji Językoznawczej Bydgoskiego Towarzystwa Naukowego" 27, 2017, s. 19.

38 H. Zapaśnik, Deep Breath, https://outride.rs/pl/deepbreath/ (dostęp: 17.11.2019).

39 M. Krauz, op. cit., s. 388. 
i graficzne (statyczne oraz dynamiczne). Zachodzi między nimi komplementarność. Mimo wspomnianych zastrzeżeń, wszystkie elementy składają się w spójną całość.

Dziewczynka z kiduszowym pucharkiem przedstawia dzieje kaliskich Żydów ${ }^{40}$. Autorzy w tym przypadku zrezygnowali z dźwięku i wideo. Uzyskali jednak dynamiczny obraz w postaci umiejscowionego w lewej części ekranu tytułowego naczynia, okręcającego się wraz z naszym przewijaniem materiału. Przedstawia jednak tylko kilka scen, które wprowadzają rozdźwięk pomiędzy sobą a treścią. Większą użyteczność stanowi ulokowany wyżej rok, zmieniający się wraz z opisywanymi w danym momencie dziejami. W przypadku tego reportażu trudno mówić o dominacji języka. Niemal wszystkie części są opatrzone przynajmniej jednym zdjęciem (te archiwalne przeplatają się ze współczesnymi, współgrając z treścią) bądź, co uatrakcyjnia przekaz, ilustracją opisywanych wydarzeń, których nie udało się uwiecznić aparatem. To autorskie grafiki zasługują w tej publikacji na szczególne uznanie - pomagają odbiorcy zwizualizować sobie czytaną historię. Zawodzi niewykorzystany potencjał tytułowego pucharka, który poprzez naniesione na niego obrazy powinien zamiast rozdźwięku wywoływać komplementarność między sobą a tekstem.

Rzemieślnik $z$ miasta pianin i fortepianów to historia Bogdana Pawlaka, jednego z pierwszych absolwentów Technikum Budowy Fortepianów w Kaliszu, oraz kaliskiej Fabryki Fortepianów i Pianin „Calisia”" ${ }^{2}$. Zdjęcia występują wyłącznie w tle, niemal na wszystkich slajdach. Przedstawiają w większości przypadków bohatera opowieści lub detale fortepianu/pianina - nawiązują więc do treści w sensie ogólnym, jednak nie do poszczególnych fragmentów, które ilustrują. Autorzy zawarli w reportażu wiele materiałów wideo (same wypowiedzi bohaterów bądź dialog z dziennikarzami): włączające się automatycznie (brak możliwości przewijania stanowi utrudnienie) lub manualnie. Uzupełniają go o treści, których w nim nie wyczytamy. Zastrzeżenia budzi jednak ich rozlokowanie - prowadzona w nich narracja często odbiega od tej w tekście znajdującym się obok. Stwarza to więc zagrożenie zaburzenia ciągłości przyswajania treści, chyba że zdecydujemy się na odbiór najpierw części językowej, a następnie audiowizualnej - co jest dopuszczalne przy tego typu publikacjach. W Rzemieślniku z miasta pianin i fortepianów obrazy (statyczne i dynamiczne) odgrywają równie istotną rolę co tekst. Zastrzeżenia budzi jednak powiązanie obu tych elementów. Przytoczone wyżej mankamenty można w prosty sposób zniwelować, co ułatwiłoby odbiór komunikatu.

Mogadishu ${ }^{42}$ szczególnie wyróżnia się na tle pozostałych analizowanych reportaży. Charakteryzuje się, jak w ich przypadku, alinearnością kompozycji - autor $\mathrm{w}$ dowolnym momencie i w dowolny sposób dodaje elementy wykraczające poza kla-

40 A. Linkowska et al., Dziewczynka z kiduszowym pucharkiem, https://outride.rs/pl/dziewczynka-z-kiduszowym-pucharkiem/ (dostęp: 17.11.2019).

${ }^{41}$ M. Berkowski et al., Rzemieślnik z miasta pianin i fortepianów, https://outride.rs/pl/fortepian/ (dostęp: 17.11.2019).

42 M. Suder, Mogadishu, https://outride.rs/pl/mogadishu/ (dostęp: 17.11.2019). 
syczny tekst (na przykład zdjęcia) ${ }^{43}$. Cechuje go jednak ponadto nielinearna narracja, co oznacza, że „chronologiczny porządek zdarzeń, organizowany przez wzorzec przyczyny i skutku, jest zaburzony lub nie istnieje"44. We wstępie czytamy krótkie wprowadzenie do przedstawianej tragedii życia w Somalii, uzupełnione przejmującymi fotografiami $\mathrm{w}$ tle oraz mapą Afryki z zaznaczonym omawianym regionem. Następnie stajemy przed wyborem jednej z sześciu historii, zatytułowanych: Chaos, Weterani, Miasto, Banadir, Przyszłość oraz Dzieci ulicy. Kolejność możemy dobierać dowolnie. Schemat każdej jest identyczny. Po wejściu odczytujemy jednoakapitowy wstęp, a następnie odsłuchujemy nagranie, wzbogacone o automatycznie przewijaną galerię zdjęć (można też bez ograniczeń przewijać fotografie ręcznie). Takie połączenie potęguje odbiór komunikatu, przez co pozostaje on w naszej pamięci na dłużej. Autor zapewnił też możliwość odczytania transkrypcji przekazu audio. Mamy więc do czynienia $\mathrm{z}$ redundancją, ale umożliwia ona zapoznanie się $\mathrm{z}$ reportażem $\mathrm{w}$ warunkach, w których nie możemy go odsłuchać, a ponadto nie wyklucza osób niesłyszących. Nie pozwala jednak na jednoczesne przeglądanie fotografii - konieczne jest zamknięcie notki. Mimo wspomnianego elementu redundantnego, całość kompozycji można ocenić jako komplementarną. Autor w prosty sposób trafnie dociera do grup o różnych potrzebach względem przyswajalności komunikatu - co wpisuje się w cele członków „Outriders”, chcących przekazywać wartościowe informacje możliwie wszystkim ludziom.

Linia to materiał o zapomnianej już w medialnym mainstreamie, toczącej się od 2014 roku, wojnie na Ukrainie ${ }^{45}$. Zaczyna się intrygująco. Po wejściu w materiał włącza się wideo, na którym dziewczynka wygrywa na pianinie wywołującą napięcie melodię. Co kilka sekund na ekranie pojawia się tytułowa czerwona linia (odzwierciedlająca podział obwodów donieckiego i ługańskiego na dwie części). Za każdym razem jest coraz grubsza i bardziej wyrazista, aż wreszcie rozlewa się na cały ekran, a muzyka milknie. Wszystkie slajdy z tekstem (nie licząc tytułowych) są zobrazowane komplementarną fotografią $\mathrm{w}$ tle przedstawiającą osoby, miejsca czy wydarzenia, o których jest mowa. Czasem zamiast zdjęcia pojawia się krótki film, pełniący taką samą funkcję, włączający się automatycznie. By jeszcze bardziej urozmaicić przekaz i zaktywizować odbiorcę, autorzy oznaczyli niektóre fragmenty tekstu na czerwono bądź zielono. Po kliknięciu w pierwsze pojawia się nowe okno z wideo lub galerią fotografii, w niektórych przypadkach opatrzonych narracją językową uzupełniającą główny tekst. Natomiast znaki zabarwione drugim z kolorów pozwalają odsłuchać rozmowy, strzały czy inne odgłosy, takie jak ładowanie magazynków. Tym samym każdy przestaje być „pasywnym odbiorcą”, a staje się „użytkownikiem, nawigatorem

43 P. Buczek, op. cit., s. 7.

44 M. Wolińska, Drogi, ścieżki, tropy. Metody konstruowania nielinearnych, interaktywnych narracji audiowizualnych na przykładzie działań studentów Katedry Sztuki Mediów, „Dyskurs: Pismo Naukowo-Artystyczne ASP we Wrocławiu" 2016, nr 22, s. 142.

45 P. Andrusieczko, M. Suder, Linia, https://outride.rs/pl/linia/ (dostęp: 17.11.2019). 
poruszającym się po hipertekście"46. Mamy więc do czynienia, w przeciwieństwie do Mogadishu, z bogactwem zastosowanych środków. Rezonują z sobą i umożliwiają wielowymiarowe poznanie przedstawionej historii. Czytelnik może kilkukrotnie wracać na przykład do dźwięków wystrzeliwanych naboi, by uświadomić sobie trud życia w opisywanym w reportażu regionie.

Ostatnim analizowanym reportażem jest Trans-Ukraina ${ }^{47}$, czyli opowieść o ludziach i historii linii kolejowej łączącej wschód kraju z jego zachodem. Napis „rozpocznij podróż" na stronie tytułowej nie odnosi się wyłącznie do metaforycznego przemierzania opisywanych miejsc. Po wejściu pojawia się wideo z wjeżdżającym na peron pociągiem, a także krótka notka między innymi o tym, że przejazd trasy zajmuje w rzeczywistości ponad trzydzieści dwie godziny. Kolejne slajdy składają się z interaktywnej mapy $\mathrm{w}$ formie linii z zaznaczonymi stacjami, zdjęcia bądź odtwarzanego automatycznie wideo w tle, informacji, w którym miejscu jesteśmy, oraz tekstu wyłaniającego się w osobnym oknie po naszej reakcji za pomocą klawiatury lub myszki. Podróż staje się o tyle realna, że odbieramy część ujęć z wnętrza pędzącego pociągu. To sprawia, że gdy docieramy do końca reportażu, możemy odczuć, jakbyśmy faktycznie przebyli najdłuższą trasę kolejową na Ukrainie. Autorzy trafnie dobrali wspomniane modalności i połączyli je komplementarnie w jedną, spójną narrację. Bogactwo możliwości znacząco angażuje odbiorcę i, co współcześnie szczególnie istotne, przyciąga jego uwagę na długo.

\section{Przyszłość dzieje się na naszych oczach, a co dalej?}

Ludzka wyobraźnia nie zna granic, o czym świadczy różnorodność przytoczonych produkcji grupy „Outriders”. Umożliwienie tworzenia przekazów multimodalnych poprzez agregację tekstu, dźwięku i obrazu (statycznego oraz dynamicznego) w żadnym razie nie warunkuje powtarzalności produkcji. Ich odbiór jest więc wzbogacony podwójnie. Przyswajanie treści za pomocą więcej niż jednego zmysłu potęguje przekaz i sprawia, że zostaje zapamiętany na dłużej. Ponadto każdy kolejny reportaż multimedialny jest dla nas czymś nowym, „do odkrycia”, a nie, jak w przypadku prasy, znaną nam już „blachą” tekstu. To nieoceniona zaleta w czasach, gdy jako społeczeństwo nudzimy się coraz częściej i coraz szybciej, a w Internecie o przyciągnięcie uwagi trzeba walczyć szczególnie. Nie bez znaczenia przy tego rodzaju realizacjach jest też fakt, iż ich „ostateczna wersja tworzona jest przez odbiorcę, który decyduje o końcowym kształcie” poprzez kolejność i sposób doboru poszczególnych elementów ${ }^{48}$.

46 K. Bałuk, op. cit., s. 84.

47 P. Andrusieczko, J. Górnicki, M. Suder, Trans-Ukraina, https://outride.rs/pl/trans-ukraina/ (dostęp: 18.11.2019).

48 A. Jakubas, op. cit., s. 144-145. 
Warto przy tym zwrócić uwagę, że produkcje podobne do tych przygotowywanych przez „Outriders” ograniczają często rolę „słowa” do niesienia informacji, przenosząc funkcję tworzenia nastroju, wzbudzania emocji czy pobudzania zmysłów na pozostałe modalności ${ }^{49}$. Podobną diagnozę, w szerszym kontekście, stawia Sabina Deditius:

Najbardziej rzucającą się w oczy właściwością dyskursów medialnych jest szerzenie się w nich obrazów, które wypierają pismo i język werbalny z roli podstawowego środka budowy dyskursu. Elektroniczne teksty przyjmują postać hipertekstu, łamiącego zasadę linearności i wykorzystującego pismo, dźwięk, fotografię, grafikę, muzykę. Wszystkie te środki współdziałają w wytwarzaniu sensu wypowiedzi, niemniej multimedialny hipertekst przyjmuje przede wszystkim postać wizualną ${ }^{50}$.

Kamil Bałuk wskazuje, że interaktywność (cechująca projekty realizowane między innymi przez „Outriders”) jest warunkiem koniecznym dla przyszłości dziennikarstwa internetowego ${ }^{51}$. Paulina Buczek twierdzi, iż reportaż multimedialny, dzięki powszechności gwarantowanej przez sieć, „zdominuje zapewne pozostałe odmiany reportażu"52 (podobnie pisze Izabela Rudnicka ${ }^{53}$ ). Choć na dominację na razie się nie zapowiada (reportaże książkowe cieszą się w naszym kraju stosunkowo dużą popularnością), a przewidywanie sytuacji na rynku za kilkadziesiąt lat jest wróżeniem z fusów, to z pewnością możemy mówić o rosnącym znaczeniu tego rodzaju materiałów. Przemawiają za tym wymienione wyżej zalety.

Nie można jednak pominąć przy tym zagrożeń. Odczytywanie reportaży multimedialnych wymaga od odbiorców „pewnej dojrzałości” ${ }^{4}$. O trudności w odbieraniu komunikatów multimodalnych pisałem już w niniejszym artykule. Nie jest to mimo wszystko determinanta rozwoju tej formy publikacji. Największe ograniczenia wiążą się z kosztami produkcji ${ }^{55}$. Samo stworzenie reportażu multimedialnego, pomijając gromadzenie materiałów, zajmuje od dwóch do trzech dni ${ }^{56}$. „Outriders” doprecyzowują, że praca nad całym projektem zajmuje tygodnie, a nawet miesiące. Próbując szacować, jak wiele środków pochłania tego typu projekt, należy pamiętać, że w większości nadal oczekujemy w Internecie bezpłatnych treści. Średnio tylko około $22 \%$ Polaków byłoby w stanie zapłacić sporadycznie, najczęściej za rozrywkę (może więc warto promować reportaże multimedialne, ze względu na ich interaktywną formę, jako rozrywkę?) ${ }^{57}$. Mimo to przyjęty przez „Outriders” model finanso-

49 Ibidem, s. 144.

50 S. Deditius, „Mental power speech”... czyli o relacji język-obraz w dyskursie polskich mówców motywacyjnych, „Prace Komisji Językoznawczej Bydgoskiego Towarzystwa Naukowego” 27, 2017 , s. 191.

51 K. Bałuk, op. cit., s. 94.

52 P. Buczek, op. cit., s. 15.

53 I. Rudnicka, Wizualizacja informacji $w$ bibliotece - od infografiki do reportażu multimedialnego, „Bibliotheca Nostra. Śląski Kwartalnik Naukowy” 52, 2018, nr 2, s. 201.

54 P. Buczek, op. cit., s. 15.

55 M. Różycka, op. cit., s. 177.

56 M. Twaróg, Historia ery przyszłości, „Nowe Media” 8, 2014, nr 2, s. 35, za: M. Różycka, op. cit., s. 177.

57 Press Club Polska, Postawy Polaków wobec mediów i płacenia za treść, Warszawa 2018, s. 6. 
wy na razie się sprawdza. Ich treści są bezpłatne, a realizacja jest opłacana ze zbiórek „czytelników”. Grupa nie akceptuje reklam i tego, by ludzie niemający pieniędzy byli odcięci „od wartościowych informacji” ${ }^{58}$. Czy możemy więc spodziewać się w przyszłości ciągłego wzrostu popularności reportaży multimedialnych? Jak konkludował w 2014 roku Marek Twaróg, redaktor naczelny „Dziennika Zachodniego”: „zamiast robić dwadzieścia bezużytecznych newsów dla nikogo, lepiej poświęcić czas na jedną porządną produkcję" 59 .

\section{Bibliografia}

Antos G., Opiłowski R., W drodze do lingwistyki obrazu. Kierunki rozwoju nowej subdyscypliny lingwistycznej z perspektywy polsko-niemieckiej, „Tekst i Dyskurs - Text und Diskurs” 8, 2015, s. 11-36.

Babik W., O natłoku informacji i związanym z nim przeciążeniu informacyjnym, Kraków 2012.

Bałuk K., Nowe formy gatunków dziennikarskich w sieci. Przykład projektów „The New York Times”, „Dziennikarstwo i Media” 5, 2014.

Buczek P., Wpływ nowych mediów na ewolucję literatury faktu: analiza reportażu multimedialnego Jacka Hugo-Badera „Boskie światto”, „Civitas et Lex” 2015, nr 3, s. 7-16.

Chrzanowska-Kluczewska E., Wycieczka multimodalna. Rola wstawek tekstowych w wizualnych dziełach sztuki, [w:] Język i tekst w ujęciu strukturalnym i funkcjonalnym, red. A. Dudziak, J. Orzechowska, Olsztyn 2017, s. 55-66.

Dąbała J., Multimodalność mediów w czasach audiowizualności a błędy w komunikowaniu, „Zeszyty Prasoznawcze" 60, 2017, nr 4, s. 707-722.

Deditius S., „Mental power speech”... czyli o relacji język-obraz w dyskursie polskich mówców motywacyjnych, „Prace Komisji Językoznawczej Bydgoskiego Towarzystwa Naukowego” 27, 2017, s. 189-196.

Frukacz K., Pogranicza reportażu - dawne i nowe, [w:] Gatunki mowy i ich ewolucja, t. 5. Gatunek a granice, red. J. Przyklenk, D. Ostaszewska, Katowice 2015, s. 419-426.

Frukacz K., Polski reportaż książkowy — przemiany i adaptacje, Katowice 2017.

Funkcjonujemy w czasach walki o uwagę odbiorców, z Natalią Osicą rozmawia Mariola Wilczak, „Biuletyn Polonistyczny" 1.08.2018.

Furman W., Kaliszewski A., Wolny-Zmorzyński K., Gatunki dziennikarskie. Teoria, praktyka, język, Warszawa 2006.

Jakubas A., Reportaż wirtualny. Nowe dziennikarstwo internetowe, [w:] Literatura bez fikcji. Między sztuka a codziennością. W stronę nowej syntezy, red. M. Hopfinger, Z. Ziątek, T. Żukowski, Warszawa 2018, s. 129-150.

Karaśkiewicz A., Spójność multimodalnego przekazu reporterskiego w krótkiej relacji telewizyjnej „na żywo", Poznań 2016.

Kawka M., Dyskurs multimodalny - nowa kategoria badawcza?, „Zeszyty Prasoznawcze” 59, 2016, nr 2, s. 294-303.

Krauz M., Zatrzymać uwage widza. Językowe i pozajęzykowe środki perswazji w telewizyjnych programach informacyjnych, „Медиалингвистика” 5, 2018, nr 3, s. 380-393.

Maćkiewicz J., Badanie mediów multimodalnych - multimodalne badanie mediów, „Studia Medioznawcze - Media Studies" 69, 2017, nr 2, s. 33-42.

58 Outriders - jakościowe dziennikarstwo...

59 M. Twaróg, op. cit., s. 35. 
Maćkiewicz J., Multimodalność a perswazja (na przykładzie tygodników opinii), „Prace Komisji Językoznawczej Bydgoskiego Towarzystwa Naukowego" 27, 2017, s. 17-25.

Press Club Polska, Postawy Polaków wobec mediów i płacenia za treść, Warszawa 2018.

Różycka M., Wykorzystanie najnowszych narzędzi cyfrowych w pracy regionalnych dziennikarzy na przykładzie „Dziennika Zachodniego”, „Zarządzanie w Kulturze” 17, 2016, nr 2, s. 167-184.

Rudnicka I., Wizualizacja informacji w bibliotece — od infografiki do reportażu multimedialnego, „Bibliotheca Nostra. Śląski Kwartalnik Naukowy" 52, 2018, nr 2, s. 189-205.

Skowronek B., Językowe odmiany medialne wobec przemian wspótczesnej technokultury, „Медиалингвистика" 5, 2018, nr 3, s. 330-338.

Sobstyl K., Funkcje obrazu i tekstu w internetowych ogłoszeniach schroniska dla bezdomnych zwierząt w Lublinie, [w:] Współczesne media. Media multimodalne, t. 2. Multimodalność mediów elektronicznych, red. I. Hofman, D. Kępa-Figura, Lublin 2018, s. 167-178.

Stöckl H., Mediolingwistyka. O statusie i metodach (nadal) konstytuujacej się dziedziny badawczej, „Tekst i Dyskurs - Text und Diskurs" 8, 2015, s. 37-61.

Świerczyńska-Głownia W., Multiplatformowa promocja treści. Prasa, radio i telewizja na sfragmentaryzowanym rynku mediów, „Zeszyty Prasoznawcze” 62, 2019, nr 1, s. 44-63.

Trysińska M., Multimodalność w szkole. Edukacyjna wartość tekstów multimodalnych na przykładzie portalu Scholaris.pl, [w:] Wspótczesne media. Media multimodalne, t. 2. Multimodalność mediów elektronicznych, red. I. Hofman, D. Kępa-Figura, Lublin 2018, s. 179-198.

Twaróg M., Historia ery przyszłości, „Nowe Media” 8, 2014, nr 2.

Wolińska M., Drogi, ścieżki, tropy. Metody konstruowania nielinearnych, interaktywnych narracji audiowizualnych na przykładzie działań studentów Katedry Sztuki Mediów, „Dyskurs: Pismo Naukowo-Artystyczne ASP we Wrocławiu" 2016, nr 22, s. 140-164.

\section{Źródła internetowe}

Andrusieczko P., Górnicki J., Suder M., Trans-Ukraina, https://outride.rs/pl/trans-ukraina/ (dostęp: 18.11.2019).

Andrusieczko P., Suder M., Linia, https://outride.rs/pl/linia/ (dostęp: 17.11.2019).

Berkowski M. et al., Rzemieślnik z miasta pianin i fortepianów, https://outride.rs/pl/fortepian/ (dostęp: 17.11.2019).

Gruszka K., Zawała M., Pokłady pamięci, https://plus.dziennikzachodni.pl/poklady-pamieci-podazajsladami-gornikow-reportaz-interaktywny/ar/c3-9061815 (dostęp: 16.11.2019).

Linkowska A. et al., Dziewczynka z kiduszowym pucharkiem, https://outride.rs/pl/dziewczynka-z-kiduszowym-pucharkiem/ (dostęp: 17.11.2019).

Outriders - jakościowe dziennikarstwo z całego świata, https://wspieram.to/outriders (dostęp: 16.11.2019).

Strona internetowa inicjatywy „Outriders”, https://outride.rs/pl/ (dostęp: 16.11.2019), https://outride.rs/ pl/interaktywnie/ (dostęp: 17.11.2019).

Strona internetowa nagrody Grand Press, https://grandpress.press.pl/ (dostęp: 16.11.2019).

Strona internetowa nagrody MediaTory, http://www.mediatory.pl/o-plebiscycie/nominowani-2017/ (dostęp: 16.11.2019).

Suder M., Mogadishu, https://outride.rs/pl/mogadishu/ (dostęp: 17.11.2019).

Zapaśnik H., Deep Breath, https://outride.rs/pl/deepbreath/ (dostęp: 17.11.2019). 


\section{A play of senses. Multimodality in Polish reporting on the basis of "Outriders"}

\section{Summary}

The overwhelming inflow of information and the rising competitiveness on the market for media require editorial offices to constantly fight for the audience's attention. At times when they, given the ever-increasing amounts of stimuli, tend to become bored in the blink of an eye, journalists wonder how to encourage them to engage in a good read. A possible solution to this problem could be the intensification of multimodality's role in media broadcasts. Such multimodality can be used in multimedia reports, which are increasing in popularity. In Poland, a group involved in such activities is called "Outriders".

Keywords: multimodality, multimedia, report, multimedia report, Outriders, digital media 